J. Biosci., Vol. 10, Number 3, September 1986, pp. 373-391. (C) Printed in India.

\title{
Purification and characterization of putrescine synthase from cucumber seedlings. A multifunctional enzyme involved in putrescine biosynthesis $\dagger$
}

\author{
G. L. PRASAD and P. R. ADIGA \\ Department of Biochemistry, Indian Institute of Science, Bangalore 560 012, India \\ MS received 26 December 1985; revised 17 May 1986
}

\begin{abstract}
The multifunctional enzyme, putrescine synthase has been purified from Cucumis sativus and characterized. This enzyme harbours agmatine iminohydrolase, ornithine transcarbamylase, putrescine transcarbamylase and carbamate kinase activities, whose concerted action results in agmatine $\rightarrow$ putrescine conversion. The enzyme resolved into two aggregation forms, enzyme aggregated and enzyme monomer upon electrophoresis at $\mathrm{pH} 8 \cdot 3$. Evidence has been provided by two-dimensional gel electrophoresis that both enzyme aggregated and enzyme monomer comprise of identical polypeptide chains. Under non-reducing conditions on sodium dodecyl sulphate-polyacrylamide gel electrophoresis, the protein moves as a single $150 \mathrm{KDa}$ polypeptide; however, in the presence of 2-mercaptoethanol on sodium dodecyl sulphate-polyacrylamide gel elec trophoresis, it migrates as 3 polypeptides of molecular weight 48,000, 44,000 and 15,000. The enzyme undergoes age-dependent in vivo proteolytic degradation from a $66 \mathrm{KDa}$ polypeptide (primary translational product), through $48 \mathrm{KDa}$ polypeptide to $44 \mathrm{KDa}$ species and finally to small molecular weight peptides.
\end{abstract}

Keywords. Multifunctional enzyme; purification; proteolysis; putrescine biosynthesis.

\section{Introduction}

Although both higher plants and micro-organisms harbour the arginine decarboxy lase pathway leading to putrescine biosynthesis, they employ entirely different sets of enzymic reactions distal to arginine decarboxylase (Adiga and Prasad, 1985; Tabor and Tabor, 1984). In micro-organisms, agmatine is cleaved to putrescine by agmatine ureohydrolase, in a reaction analogous to that of arginase (Tabor and Tabor, 1972; Morris and Pardee, 1966), whereas in plants, putrescine was presumed to be derived from a two-step hydrolysis of agmatine, catalysed by agmatine iminohydrolase and N-carbamyl putrescine amidohydrolase (Smith, 1963, 1965, 1970, 1971; Smith and Garraway, 1964). As against the above scheme of conversion of agmatine to putrescine proposed in plants, our recent work with

\footnotetext{
$\uparrow$ Preliminary results of this work were presented at Golden Jubilee and Annual General Body Meetings of Society of Biological Chemists (India) and the Second Congress of Asian and Ocean Biochemists (1980) held at Bangalore, 1981, Indian J. Biochem. Biophys., 18, 113.

Abbreviations used: PAGE, Polyacrylamide gel electrophoresis; SDS, sodium dodecyl sulphate; IgG, immunoglobulin G; BSA, bovine serum albumin; EA, enzyme aggregated; EM, enzyme monomer; CH-Sepharose, Carboxyhexyl-Sepharose; Mr,' molecular weight; PMSF, phenyl methyl sulphonyl fluoride; DTT, dithiothreitol.
} 
Lathyrus sativus seedlings has implicated the involvement of a versatile polycepha lic enzyme viz., 'putrescine synthase'* catalyzing these reactions. It was shown that due to the concerted action of its component enzymic activities (viz., agmatine iminohydrolase, ornithine transcarbamylase, putrescine transcarbamylase and carbamate kinase), putrescine synthase converts agmatine to putrescine. The scheme of reactions catalyzed by this enzyme not only explains the nonaccumulation of $\mathrm{N}$-carbamyl putrescine in the plant but also envisages the conservation of labile carbamyl moiety in terms of cellular economy (Srivenugopal and Adiga, 1981, 1983a). During these studies, preliminary evidence was adduced for the operation of a similar sequence of reactions leading to putrescine elaboration in other plant systems including cucumber seedlings. However, it was not explored whether there is any discernible difference in terms of molecular characteristics of putrescine synthase from different higher plant systems. To investigate this possibility the purification and characterization of putrescine synthase from Cucumis sativus seedlings was undertaken and this paper deals with these aspects as well as the details of the reactions catalyzed by the purified enzyme protein.

\section{Materials and methods}

\section{Materials}

The following chemicals were purchased from Sigma Chemical Company, St. Louis, Missouri, USA: micrococcal nuclease, Triton X-100, creatine Phosphoki nase, creatine phosphate, GTP and oligo(dT) cellulose. $\left[{ }^{14} \mathrm{C}\right]-U r e a$ (Sp. Activity $38 \mathrm{mCi} / \mathrm{m} \mathrm{mol}$ ) and $\mathrm{H}_{2}{ }^{35} \mathrm{SO}_{4}$ (carrier-free) were procured from Bhabha Atomic Research Centre, Bombay. Sources of other chemicals and cucumber seeds were same as referred to earlier (Srivenugopal and Adiga, 1981).

Since significant amounts of impurities present in commercial carbamyl phosphate interfered with the colorimetric assay employed, carbamyl phosphate was purified as described earlier (Srivenugopal and Adiga, 1981). ADP obtained commercially also harboured detectable amounts of ATP which interfered with the kinase assay (Lamprecht and Trautschold, 1974). The contaminant ATP was converted to ADP by treating with hexokinase prior to purification by chromatography on a. Dowex-1 column (Cohen and Carter, 1950).

Both radioactive (Sp. activity $30 \mu \mathrm{Ci} / \mathrm{m}$ mol) and non-radioactive $\mathrm{N}$-carbamyl putrescine were synthesized and purified according to the procedure detailed elsewhere (Srivenugopal and Adiga, 1980, 1983b). $\left[{ }^{35} \mathrm{~S}\right]-$ Methionine was prepared from Escherichia coli strain B grown on neutralized carrier-free $\mathrm{H}_{2}{ }^{35} \mathrm{SO}_{4}$ according to the method of Crawford and Gesteland (1973).

\footnotetext{
* Multifunctional enzyme with constituent activities of agmatine iminohydrolase $($ EC $3 \cdot 5 \cdot 3 \cdot 12)$, putrescine transcarbamylase (EC 2136), ornithine transcarbamylase (EC 213.3) and carbamate kinase $($ EC $2 \cdot 7 \cdot 2 \cdot 2)$.
} 


\section{Methods}

Putrescine carboxyhexyl-Sepharose for affinity chromatography: Putrescine carboxyhexyl-Sepharose (CH-Sepharose) was prepared as described earlier (Srivenu gopal and Adiga, 1981).

Gel electrophoresis: Polyacrylamide gel electrophoresis (PAGE) under nondenaturing and denaturing conditions was carried out as detailed elsewhere (Davis, 1964; Laemmli, 1970).

Preparative electrophoresis: Preparative electrophoresis at $\mathrm{pH} 8 \cdot 3$, was carried out on $5 \%$ acrylamide slab gels (Davis, 1964). The regions of interest on the unstained slab gel were cut into small pieces and placed in glass tubes $(1 \times 13 \mathrm{~cm})$ which had polymerized $3 \%$ acrylamide as the base. The bottoms of the tubes containing the polymerized gel were tied with dialysis tubing and electrophoresed for 18-24 h at $4^{\circ} \mathrm{C}$. The electroeluted protein, collected in dialysis tubings was concentrated over sucrose and dialyzed against $10 \mathrm{mM}$ Tris- $\mathrm{HCl}$, $\mathrm{pH} 7.6$ containing $0.5 \mathrm{mM} \mathrm{Mn}{ }^{2+}$ and $2 \mathrm{mM}$ 2-mercaptoethanol*.

Two-dimensional gel electrophoresis: Two-dimensional gel electrophoresis was carried out at $\mathrm{pH} 8 \cdot 3$ in the first dimension and sodium dodecyl sulphate (SDS)-PAGE as the second dimension. First dimension electrophoresis was carried out on $5 \%$ acrylamide gels, either in tubes or on slabs. A parallel tube/slot, which contained tracking dye was stained with the instant stain. The equilibrated gel was placed over the second dimension gel and sealed with $0.8 \%$ agarose and electrophoresis was carried out as described.

\section{Immunological techniques}

Preparation of antiserum: Albino rabbits (2 $\mathrm{kg}$ body wt.) were administered subcutaneously once a week with $100 \mu g$ of the purified enzyme protein in Tris-buffered saline, emulsified with equal volume of Freund's complete adjuvant at multiple sites. After 3 injections, a booster dose of $1 \mathrm{mg}$ protein in saline was administered. After 6 days, animals were bled through the ear vein, serum separated and stored frozen. The immunoglobulin $G$ (IgG) fraction from the antisera was prepared according to Cambell et al. (1970). Ouchterlony double immunodiffusion and Immunoelectrophoresis were performed as described (Ouch terlony, 1967).

Immunoprecipitation: Known amounts of isolated enzyme protein and the IgG from the antisera to the enzyme (specific) or the antiserum raised to bovine serum albumin (BSA) were added to tubes containing the immunoprecipitation buffer (Tris-HCl buffer, $\mathrm{pH} 7.2,0 \cdot 1 \mathrm{M} ; 0 \cdot 1 \mathrm{M} \mathrm{NaCl} ; 0.5 \%$ Triton X-100) and incubated at $37^{\circ} \mathrm{C}$ for $1 \mathrm{~h}$ followed by standing at $4^{\circ} \mathrm{C}$ for $24 \mathrm{~h}$. The immunoprecipitates were collected by centrifugation and washed 4 times with the above buffer. The final washing was carried out with the same buffer but without the detergent. When

* Unless otherwise stated from now onwards $10 \mathrm{mM}$ Tris- $\mathrm{HCl}, \mathrm{pH} 7 \cdot 6$ containing $0.5 \mathrm{M} \mathrm{Mn}^{2+}$ and

$2 \mathrm{mM} 2$-mercaptoethanol is referred to only as buffer. 
radioactive antigens were to be immunoprecipitated, the washing buffer also contained the corresponding non-radioactive amino acid to minimize non-specific trapping of labelled protein.

Enzyme assays: The different component activities of the multifunctional enzyme, putrescine synthase, viz., agmatine iminohydrolase, ornithine carbamylase, putres cine transcarbamylase and carbamate kinase and the overall reactions linked to either ornithine carbamyl transferase or carbamate kinase were assayed essentially as described elsewhere (Srivenugopal and Adiga, 1981). Unless otherwise stated, all the enzyme assays were conducted at $37^{\circ} \mathrm{C}$ for $2 \mathrm{~h}$; carbamyl transferases were quantitated at $25^{\circ} \mathrm{C}$ for $30 \mathrm{~min}$.

Definition of unit activity: Unless otherwise stated one unit activity is defined as the amount of enzyme required to produce $1 \mu$ mol of product $\left(\mathrm{NH}_{3}, \mathrm{~N}\right.$-carbamyl putrescine, citrulline or ATP $/ \mathrm{h}$ under standard assay conditions. Specific activity is expressed in units/mg of protein.

Other methods: Identification of amine products by paper chromatography was accomplished according to Srivenugopal and Adiga (1981). Protein was estimated according to Lowry et al. (1951) using crystalline BSA as a standard.

RNA was extracted from 6-day old cucumber seedlings (Palmiter, 1974) and poly $(\mathrm{A})^{+}$RNA was separated from the total RNA on oligo(dt)-cellulose (Aviv and Leder, 1972). In vitro translation of isolated poly (A) ${ }^{+}$RNA was carried out in rabbit reticulocyte lysates according to Ravishankar and Padmanaban (1983). Homologous translation using a supernatant fraction from $\mathrm{S}_{27}$ homogenates after centrifugation at $4^{\circ} \mathrm{C}$ at $27,000 \mathrm{~g}$ of 6 -day old cucumber cotyledons was performed according to the protocol adopted by Srivatsan and Padayatty (1976).

\section{Purification of cucumber putrescine synthase}

In order to determine the particular developmental stage of the seedlings at which the putative putrescine synthase can be isolated with satisfactory yields, the enzyme was extracted at different stages of the plant development. The component activities were estimated in the crude enzyme extracts (see below). The results (figure 1) clearly indicated that all the enzyme activities peak at day 6 of seedling growth and slowly decline thereafter. In view of these observations 6-day old seedlings were employed as the source for enzyme purification.

Thoroughly washed plant tissue was homogenized in a precooled Waring blender or by grinding in a glass pestle and mortar with glass powder in the presence of $20 \mathrm{mM}$ Tris-HCl buffer, $\mathrm{pH} 8.5$ containing $5 \mathrm{mM} 2$-mercaptoethanol and $0.5 \mathrm{mM} \mathrm{MnCl}_{2}$ and centrifuged at $15,000 \mathrm{~g}$ for $15 \mathrm{~min}$. Unless otherwise stated all the operations were carried out at $4^{\circ} \mathrm{C}$. When used for activity assays the clear supernatant was dialyzed against $10 \mathrm{mM}$ Tris- $\mathrm{HCl}, \mathrm{pH} 7.5$ containing $2 \mathrm{mM}$ 2-mercaptoethanol and $0.5 \mathrm{mM} \mathrm{Mn}^{2+}$ and the clarified protein fraction was employed for further purification. The crude extract was adjusted to $7.5 \mathrm{mM} \mathrm{MnCl} \mathrm{M}_{2}$ concentration and stirred for $60 \mathrm{~min}$. Precipitated nucleoproteins were removed by centrifugation.

The clarified $\mathrm{MnCl}_{2}$-supernatant was brought to $90 \%$ saturation with ammonium sulphate and stirred for $1 \mathrm{~h}$ to complete precipitation. The precipitate was collected by centrifugation and dissolved in a minimum volume of $50 \mathrm{mM}$ Tris- $\mathrm{HCl}$ buffer, 


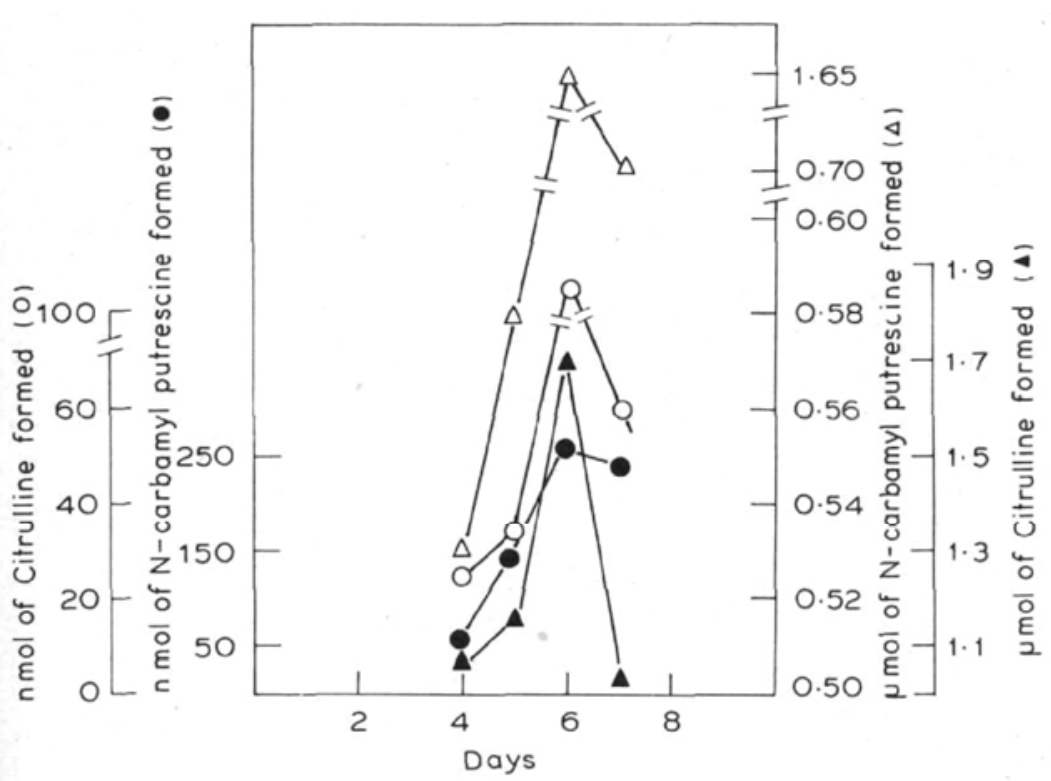

Figure 1. Changes in the component activities of putrescine synthase during the development of cucumber seedlings.

Cucumber seedlings were harvested at various stages of growth and crude enzyme extracts were prepared as described in 'methods'. Agmatine iminohydrolase, putrescine transcarbamylase, ornithine transcarbamylase and the complete reaction (agmatine+ ornithine $P_{i}$ citrulline + putrescine $+\mathrm{NH}_{3}$ ) were measured.

$(\Delta)$, Ornithine transcarbamylase; $(\Delta)$, putrescine transcarbamylase; $(\mathbf{O})$, agmatine iminohydrolase; $(\mathrm{O})$, complete reaction.

pH 8.0 containing $2 \mathrm{mM}$ 2-mercaptoethanol and $0.5 \mathrm{mM} \mathrm{Mn}^{2+}$ and desalted on a Sephadex G-25 $(2 \times 75 \mathrm{~cm}$; coarse 100-300 $\mu)$ column pre-equilibrated with buffer. The salt-free ammonium sulphate precipitated fraction was applied onto a column of putrescine-CH-Sepharose $(10 \mathrm{ml}$ bed volume; $1.5 \times 7.5 \mathrm{~cm})$ pre-equilibrated with buffer and recycled. The column was washed extensively with buffer to remove the unbound proteins and elution of the column with $5 \mathrm{mM}$ putrescine resulted in dislodging of the bound protein as a single peak (data not shown). The dialysed, pooled protein fraction, when assayed harboured all the constituent activities of putrescine synthase and gave positive results when tested for the overall reactions (viz., agmatine + ornithine $\rightarrow$ putrescine + citrulline + ammonia). At this stage, the protein essentially resolved into two bands, enzyme aggregated (EA) and enzyme monomer (EM) on alkaline PAGE (figure 2a). These two bands were not separable by other techniques like gel filtration on Sephadex G-200 or ion-exchange chromatography on DEAE-cellulose. 


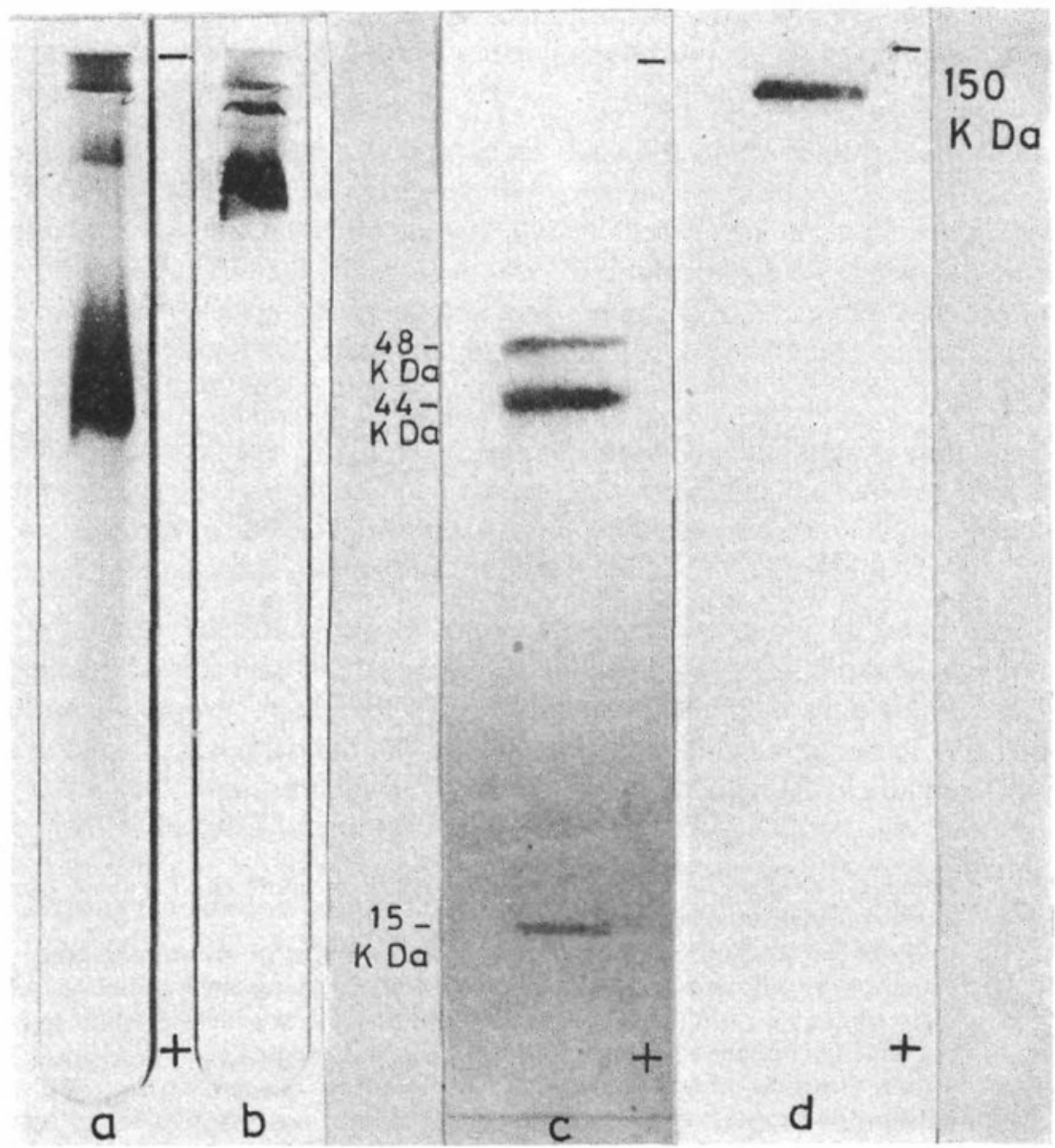

Figure 2. PAGE of putrescine Sepharose eluate.

(a, b), Electrophoresis at $\mathrm{pH} 8 \cdot 3$ under non-denaturing conditions for $6 \mathrm{~h}$ and $3 \mathrm{~h}$, respectively on $7 \cdot 5 \%$ acrylamide gels, (c, d), Electrophoresed in the presence of SDS under reducing and non-reducing conditions respectively on $10 \%$ acrylamide gels. Protein load of about $150 \mu \mathrm{g}$ was employed in each case.

\section{Results}

\section{Purification of the enzyme}

Putrescine synthase from the cucumber seedlings was purified by affinity chromatography on putrescine $\mathrm{CH}$-Sepharose, the procedure developed for purification of L. sativus enzyme (Srivenugopal and Adiga, 1981). However, the recovery of the enzyme activities was relatively less satisfactory (tables 1 and 2). The expected constant ratios of specific activities of constituent enzyme activities during different stages of purification as a criterion for association of different enzyme activities with a single protein, could not be demonstrated because of uncontrolled proteolytic degradation, the existence of more than one catalytically 


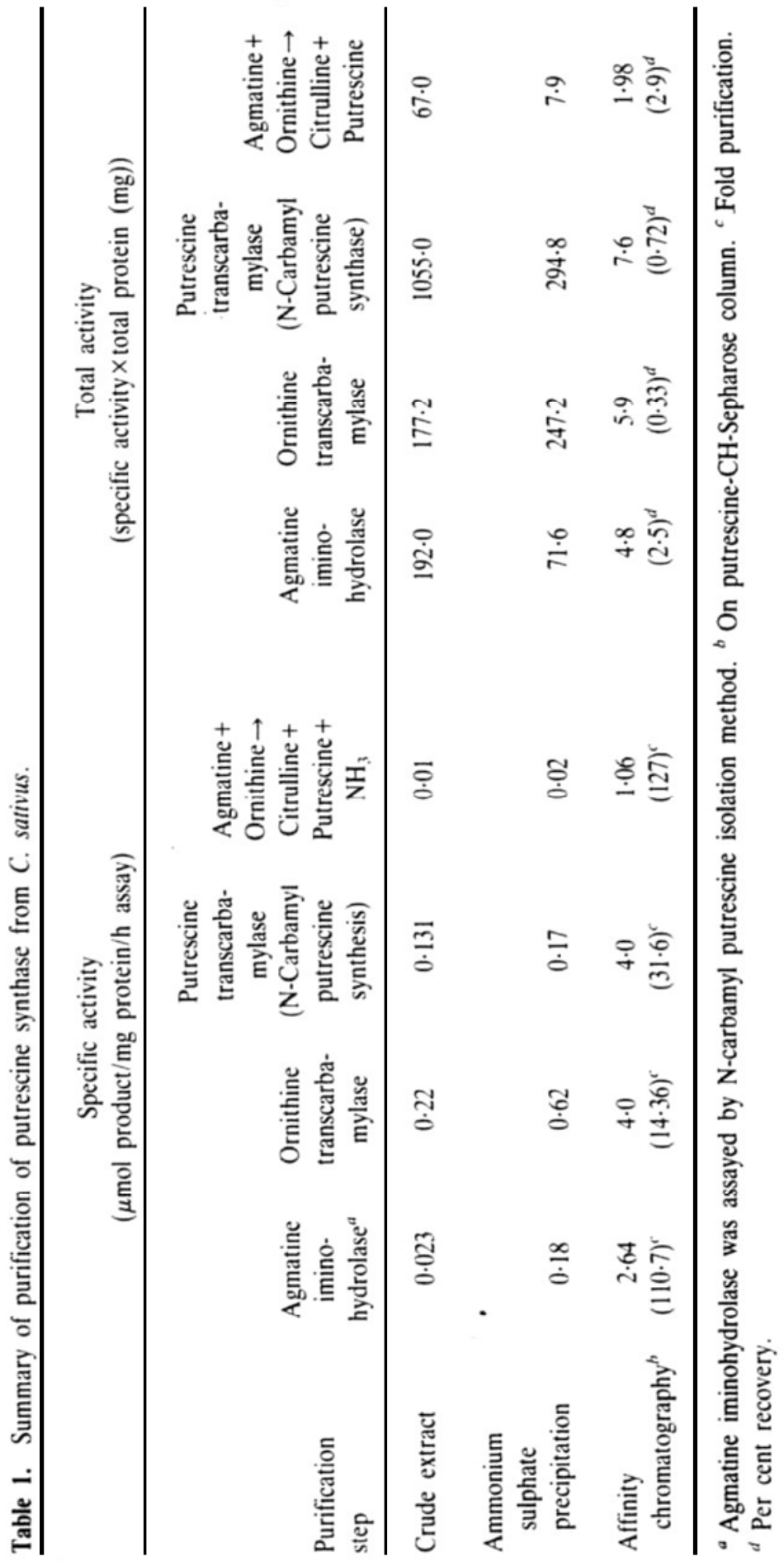


Table 2. Purification of carbamate kinase (component of multifunctional enzyme, putrescinc synthase) from cucumber seedlings.

\begin{tabular}{|c|c|c|c|}
\hline \multirow[b]{2}{*}{ Purification step } & \multicolumn{3}{|c|}{$\begin{array}{l}\text { Specific activity units }(\mu \mathrm{mol} \text { of ATP } \\
\text { produced } / \mathrm{mg} \text { protein } / \mathrm{h})\end{array}$} \\
\hline & $\begin{array}{c}\text { Carbamyl phosphate }+ \\
\mathrm{ADP}+P_{1} \rightarrow \\
\mathrm{ATP}+\mathrm{NH}_{3}+\mathrm{CO}_{2}\end{array}$ & $\begin{array}{c}\mathrm{N} \text {-Carbamyl } \\
\text { putrescine }+\mathrm{ADP}+P_{i} \\
\text { ATP }+ \text { Putrescine }+ \\
\mathrm{NH}_{3}+\mathrm{CO}_{2} \\
\end{array}$ & $\begin{array}{c}\text { Agmatine }+ \text { ADP }+ \\
P_{i} \rightarrow \\
\text { ATP }+ \text { Putrescine }+ \\
2 \mathrm{NH}_{3}+\mathrm{CO}_{2} \\
\end{array}$ \\
\hline Crude extract & $0 \cdot 049$ & $0 \cdot 05$ & $0 \cdot 028$ \\
\hline $\mathrm{MnCl}_{2}$ supernatant & $0 \cdot 05$ & 0.05 & $0 \cdot 03$ \\
\hline $\begin{array}{l}\text { Ammonium sulphate } \\
\text { precipitation }\end{array}$ & 0.474 & $0 \cdot 03$ & 0.129 \\
\hline DEAE-cellulose & $0 \cdot 143$ & $0 \cdot 079$ & 0.179 \\
\hline Affinity eluate & - & - & 0.523 \\
\hline
\end{tabular}

active molecular species and the labile nature of the constituent enzyme activities as purification progressed. Estimation of $\mathrm{NH}_{3}$ for assaying agmatine iminohydrolase activity during the early steps of purification also proved unsatisfactory because of the presence of 3 types of amine oxidases in this plant system, all utilizing agmatine as substrate (Percival and Purves, 1974) (data not given). Chromatography on DEAE-cellulose was found necessary as an additional purification step prior to affinity chromatography to enhance the efficacy of the affinity matrix. The final purification protocol employed was in brief as follows: the protein from ammonium sulphate precipitation step was loaded onto a DEAE-cellulose column preequilibrated with the buffer; this was followed by sequential washing of the column with the buffer and $0.1 \mathrm{M} \mathrm{KCl}$, and subsequent elution of the adsorbed protein with $0.3 \mathrm{M} \mathrm{KCl}$. The resultant enzyme preparation exhibited all the component enzyme activities of putrescine synthase described earlier (Srivenugopal and Adiga, 1981). The protein was concentrated by ammonium sulphate precipitation and desalted by exclusion on Sephadex G-25 column. This concentrated DEAEcellulose eluted protein was finally applied onto putrescine $\mathrm{CH}$-Sepharose used as a column.

\section{Molecular characteristics of the enzyme}

On electrophoresis at $\mathrm{pH} 8 \cdot 3$, putrescine-Sepharose eluate was resolved into two protein bands (EA and EM) on both $7 \cdot 5 \%$ or $5 \% \mathrm{p}$ olyacrylamide gels. No additional bands could be detected even when the protein as high as 150-200 $\mu \mathrm{g}$ was loaded to detect possible presence of other minor species. Only when protein load was large $(200 \mu \mathrm{g})$ a characteristic stainable streak was observed (figure 2a,b). Results of two-dimensional gel electrophoresis show that the two molecular entities resolved on electrophoresis represent the same protein, but with different degrees of aggregation.

\section{Gel filtration}

When the affinity purified preparation was loaded onto a Biogel-P-300 column, the protein was eluted in the void volume. Agmatine iminohydrolase activity of the 
excluded protein (assayed as a representative of component activities of putrescine synthase) was comparable to that of the putrescine $\mathrm{CH}$-Sepharose eluate on unit protein basis (data not shown). The stainable protein pattern resolved on the gel during SDS-PAGE was also identical in both cases. It would therefore appear that both $48 \mathrm{KDa}$ and $44 \mathrm{KDa}$ polypeptides along with the minor degradation products exist as a large molecular entity which could not be resolved into the components under milder conditions of gel filtration.

\section{SDS-PAGE}

When either the putrescine-Sepharose eluate or the two constituent molecular species separated on PAGE was individually subjected to SDS-PAGE under non-reducing conditions, a single stainable protein band with a molecular weight $\left(M_{r}\right)$ of 150,000 was observed (figure $\left.2 \mathrm{~d}\right)$. However, in the presence of $2 \%(\mathrm{v} / \mathrm{v})$ 2-mercaptoethanol, two well defined bands viz., $48 \mathrm{KDa}$ and $44 \mathrm{KDa}$ polypeptides besides other fast moving small $M_{r}$ peptides (figure 2c) were observed in each of these cases. The small $M_{r}$ peptides observed presumably represent proteolytic degradation products of the protein either in vivo or during purification. However, the appearance of the two bands of higher $M_{r}$ viz., 48,000 and 44,000 with almost equal intensity is not easily explained at this stage and may represent proteolytic degradation products of a single protein species or two different types of subunits held together by disulphide bonds.

\section{Relationship between the two enzyme forms}

Conclusive evidence that these two molecular species (i.e., E A and EM) represent different forms of the same basic unit, stems from analysis by two-dimensional gel electrophoresis. The protein separated as EA and EM components on alkaline gels was subjected to SDS-PAGE in the second dimension (figure 3). Both EA and EM exhibited identical pattern on gels since both of them consisted predominantly of $48 \mathrm{KDa}$ and $44 \mathrm{KDa}$ species. Efforts to minimize the appearance of the multifunc tional protein in the two aggregated states by adding detergents like Triton X-100 during purification proved futile.

\section{Evidences for proteolytic degradation}

As indicated earlier, the multiple protein bands observed in SDS-PAGE presumably reflect proteolytic degradation of the enzyme. In an attempt to prevent proteolysis, phenyl methyl sulphonyl fluoride (PMSF) at 0.1 and $1.0 \mathrm{mM}$ concentrations was included in the buffers during tissue homogenization as well as subsequent steps; but this could not curtail the appearance of the enzyme protein as $48 \mathrm{KDa}$ and $44 \mathrm{KDa}$ species on SDS-PAGE to any discernible extent indicating that this phenomenon represents an in vivo situation. Supporting evidence for the above arises from the observation that the enzyme protein prepared from the seedlings at different stages of development showed variable relative proportions (as assessed from their staining intensity) of $48 \mathrm{KDa}$ and $44 \mathrm{KDa}$ species on SDS-PAGE in the presence of 2-mercaptoethanol, despite the fact that under non-reducing conditions, the protein uniformly exhibited $M_{r}$ of 150,000 . That the age-dependent in vivo proteolysis was responsible for these observations is 




Figure 3. Two-dimensional gel electrophoresis of cucumber putrescine synthase.

The enzyme was resolved to EA and EM on 5\% acrylamide gels at $\mathrm{pH} 8.3$ and then placed over a $10 \%$ SDS Polyacrylamide after treatment with $01(\mathrm{w} / \mathrm{v})$ and $2 \%(\mathrm{v} / \mathrm{v})$ 2-mercaptoethano for $30 \mathrm{~min}$ and electrophoresed. The positions of EA and EM in the first dimension gel are indicated in the figure.

suggested by the finding that the enzyme purified from 4-day old seedlings exhibited predominantly a $66 \mathrm{KDa}$ split-band and relatively much lesser amounts of $48 \mathrm{KDa}$ and $44 \mathrm{KDa}$ polypeptides. By day 6 , the $66 \mathrm{KDa}$. species seemed to disappear with concomitant emergence of a greater proportion of $48 \mathrm{KDa}$ and $44 \mathrm{KDa}$ species. In contrast, the protein purified from the day 7 seedlings showed primarily the $44 \mathrm{KDa}$ polypeptide (figure 4). Repeated attempts to inhibit the proteolytic degradation by adding PMSF to homogenization buffer during extraction of the enzyme from day 4 seedlings were unsuccessful, showing thereby that this is mostly an in vivo phenomenon. 


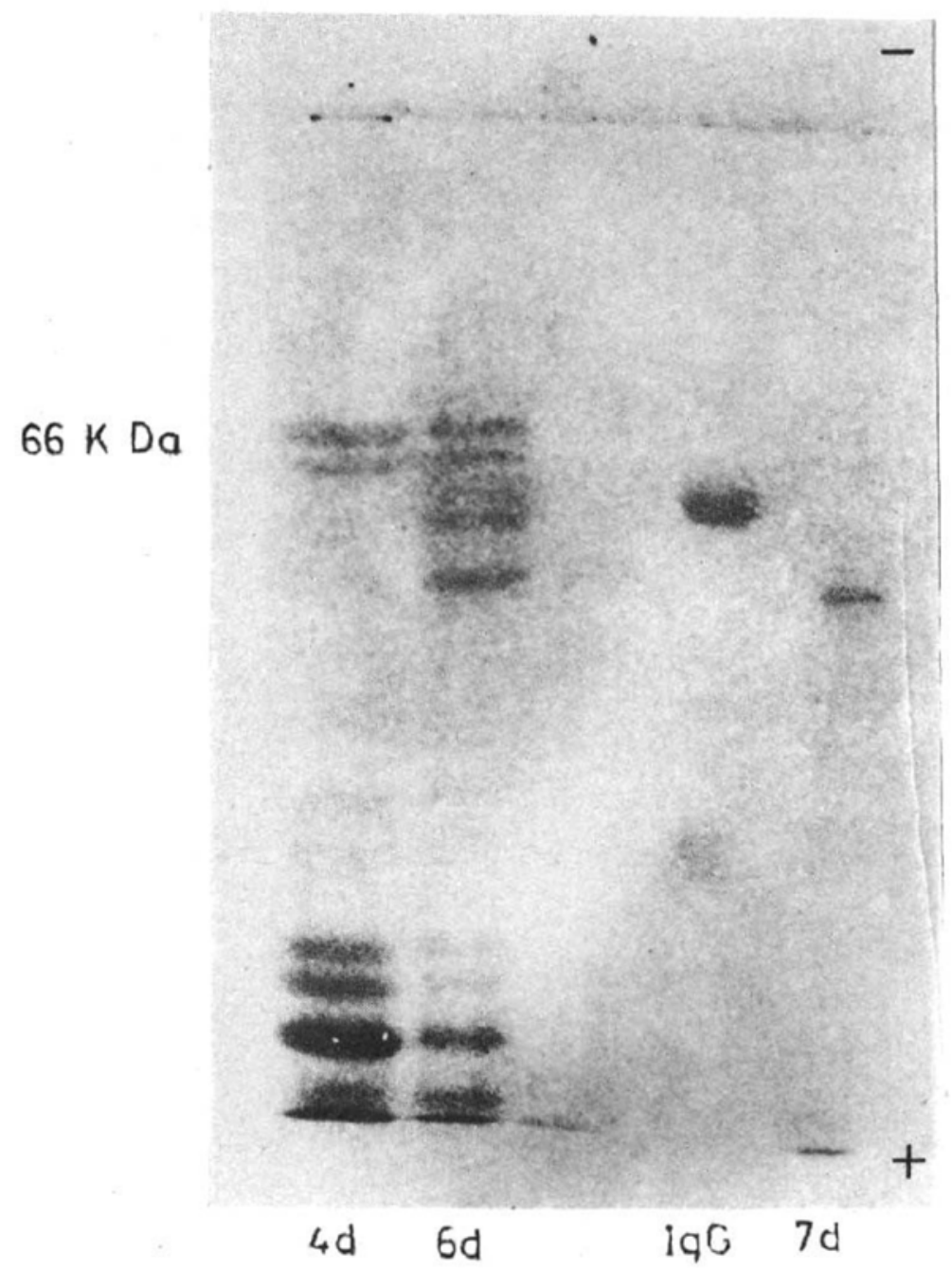

Figure 4. In vivo age-dependent degradation of putrescine synthase.

Putrescine synthase was isolated by a single step affinity chromatography at different stages of the seedling development and subjected to SDS-PAGE

In vitro translation of mRNA in the rabbit reticulocyte cell-free system

The nature and molecular size of the primary translation product of mRNA from 6-day old seedlings was isolated and translated in rabbit reticulocyte system (see 'materials and methods')- The radioactively labelled translational products were immunoprecipitated with $\mathrm{IgG}$ prepared from the putrescine synthase antiserum and analyzed on $7 \cdot 5 \%$ SDS-PAGE and fluorography. It could be clearly seen that a single band of $M r 66,000$ lighted up in the fluorograph (figure 5a). It would appear therefore that a molecular species of $66 \mathrm{KDa}$ is the primary translational product which in turn undergoes proteolytic modification either during or subsequent to assembly of putrescine synthase complex. 




Figure 5. In vitro translation of cucumber putrescine synthase.

(a), The RNA isolated from 6-day old cucumber seedlings was translated in the reticulocyte lysate system and immunoprecipitated with IgG fraction of the antiserum raised against purified putrescine synthase and immunoprecipitates were analyzed on $7 \cdot 5 \%$ SDS-PAGE and monitored by fluorography. Lane (i) total RNA $5 \mu \mathrm{g}$ and (ii) $2 \mu \mathrm{g}$ of poly $(\mathrm{A}+) \mathrm{RNA}$.

(b), Cucumber cotyledon extracts active in protein synthesis (S27 fraction) were prepared as described in 'materials and methods'. Cell-free synthesis of the enzyme was carried out by using endogenous messengers, immunoprecipitated and analyzed as described above. Lane (i) immunoprecipitated using specific IgG and (ii) immunoprecipi tated using IgG prepared from antiserum to bovine serum albumin.

\section{Cell-free synthesis of putrescine synthase using homologous translation system}

In order to examine the nature of primary translation product synthesized in the homologous cell-free translation system with all the enzymatic machinery required to process putrescine synthase, the active extracts from the cucumber cotyledons 
capable of supporting $\left[{ }^{35} \mathrm{~S}\right]$-methionine incorporation into the protein were prepared as described and translation carried out using endogenous mRNA. Upon analyzing the immunoprecipitated proteins on SDS-PAGE it became evident, that in addition to the expected protein species of $66 \mathrm{KDa}$, significant amount of $48 \mathrm{KDa}$ species were detectable (figure 5b). This clearly supported the earlier finding that proteolytic processing of the putrescine synthase complex is inherent to the cucumber seedlings (figure $5 \mathrm{~b}$ ).

\section{Evidence for proteolys is from immunological techniques}

When the purified IgG from the specific antiserum raised against the putrescine $\mathrm{CH}-\mathrm{Sepharose}$ eluate was allowed to cross-react with the multifunctional protein during different stages of purification, a single precipitin line was observed both during double immunodiffusion and Immunoelectrophoresis (figure 6a,b). This
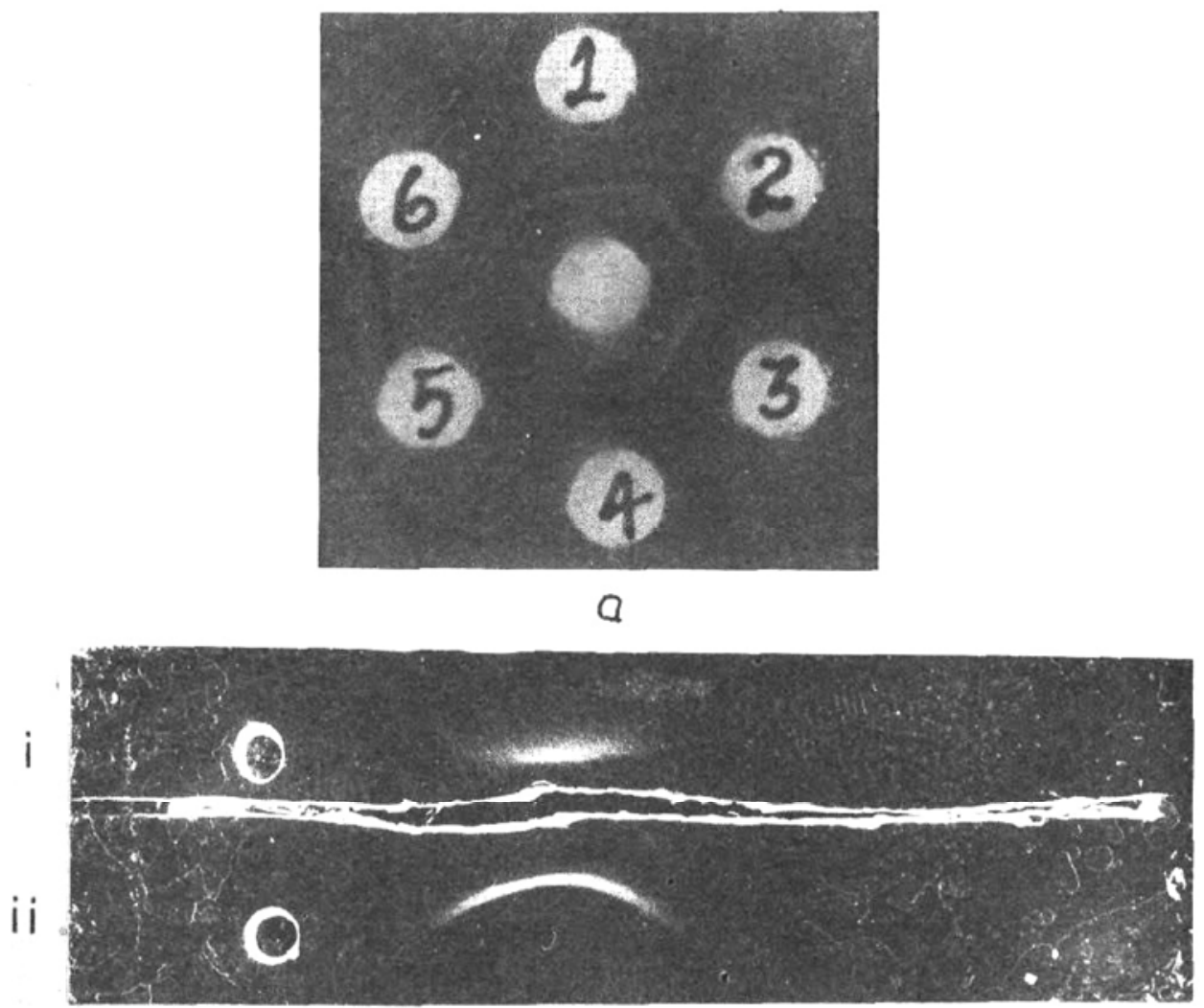

b

Figure 6. Ouchterlony immunodouble diffusion.

The centre well contained IgG prepared from the antiserum raised against putrescine Sepharose eluate. Outer wells contained the protein fractions from (1) crude extracts, (2) $\mathrm{MnCl}_{2}$ supernatant, (3) DEAE-cellulose eluate, (4) and (6) putrescine Sepharose eluate and (5) BSA.

Immunoelectrophoresis: The centre trough contained specific IgG for putrescine synthase. The well contained (i) crude extracts of cucumber seedlings and (ii) putrescine Sepharose eluate. 
clearly attests to both the specificity of the antibody and the immunochemical purity of the isolated putrescine synthase.

To ascertain the purification step at which the maximum proteolysis of the enzyme protein becomes evident, putrescine synthase was immunoprecipitated at different stages of the purification and analyzed by SDS-PAGE. Proteolytic degradation of the protein becomes discernible in crude extracts itself and throughout the purification protocol employed, this same degradation pattern more or less persists (data not shown).

\section{General properties}

Putrescine synthase was highly unstable since all the component activities as well as complete reactions seemed to rapidly decrease as purification progressed. Owing to the presence of more than one species of the enzyme at any stage of purification constant ratios of the component activities at different stages of purification could not be obtained. On the premise that such small $M_{r}$ degradation products may be inhibitory to the catalytic activity(ies), further purification of the two enzyme species EA and EM by preparative electrophoresis and the individual constituent enzyme activities were analyzed; this led to dramatic improvement in the catalytic efficiencies of all the activities associated with both E A and EM; E A displayed higher specific activity on unit $A_{280} \mathrm{~nm}$ basis for all the component activities as well as of the complete reaction, compared to EM (table 3). The reaction viz., $\mathrm{N}$-carbamyl putrescine + ornithine $\rightarrow$ putrescine + citrulline $+\mathrm{NH} 3$, which could not readily be quantified in the affinity eluate or resolved EM, was clearly assayable with EA. Agmatine iminohydrolase activity was 3 times higher in EA than in EM, on unit protein basis. Further characterization of these component activities or the overall reactions were severely hampered by the poor yields and instability of the enzyme preparations. For example, the carbamate kinase activity which could be unequivocally demonstrated upto DEAE-cellulose chromatography step could not reproducibly be assayed individually after affinity chromatography. However, its

Table 3. Component activities of putrescine synthase in EA, EM and putrescine-Sepharose eluate.

\begin{tabular}{|c|c|c|c|c|c|c|}
\hline \multirow[b]{2}{*}{$\begin{array}{l}\text { Enzyme } \\
\text { Source }\end{array}$} & \multicolumn{2}{|c|}{$\begin{array}{c}\text { Agmatine } \\
\text { iminohydrolase }\end{array}$} & \multirow[b]{2}{*}{$\begin{array}{c}\text { Ornithine } \\
\text { trans- } \\
\text { carbamylase }\end{array}$} & \multirow{2}{*}{$\begin{array}{c}\text { Putrescine } \\
\text { transcarba- } \\
\text { mylase } \\
\text { (N-Carbamyl- } \\
\text { putrescine } \\
\text { synthase) }\end{array}$} & \multirow{2}{*}{$\begin{array}{c}\text { Agmatine }^{a} \\
\text { Ornithine } \\
\qquad \rightarrow \\
\text { Citrulline + } \\
\text { Putrescine + } \\
\mathrm{NH}_{3}\end{array}$} & \multirow{2}{*}{$\begin{array}{c}\text { N-Carbamyl } \\
\text { putrescine + } \\
\text { Ornithine }{ }^{a} \\
\rightarrow \\
\text { Citrulline+ } \\
\text { Putrescine }\end{array}$} \\
\hline & $\mathrm{NH}_{3}$ & $\begin{array}{l}\text { N-Carbamyl } \\
\text { putrescine } \\
\text { synthesis }\end{array}$ & & & & \\
\hline \multicolumn{7}{|l|}{ Putrescine- } \\
\hline $\begin{array}{l}\text { Sepharose } \\
\text { eluate }\end{array}$ & 0.687 & 0.7 & 0.436 & $3 \cdot 8$ & $0 \cdot 218$ & $\begin{array}{c}\text { Not } \\
\text { detectable }\end{array}$ \\
\hline EA & $3 \cdot 0$ & $3 \cdot 1$ & $4 \cdot 6$ & $10 \cdot 4$ & $1 \cdot 25$ & 1.43 \\
\hline EM & $1 \cdot 3$ & $1 \cdot 2$ & 3.9 & $5 \cdot 9$ & 0.072 & 0.072 \\
\hline
\end{tabular}

Activities expressed as $\mu \mathrm{mol}$ of roduct formed $/ \mathrm{mg} / \mathrm{h}$.

${ }^{a}$ Citrulline was quantitated in the complete reactions linked to ornithine transcarbamylase. 
participation in the overall reaction linked to carbamate kinase (viz., agmatine $+\mathrm{ADP}+\mathrm{Pi} \rightarrow \mathrm{ATP}+$ putrescine $+2 \mathrm{NH}_{3}+\mathrm{CO}_{2}$ ) could be convincingly demon strated. The other two reactions viz., carbamyl phosphate + ADP $\rightarrow$ ATP $+\mathrm{NH}_{3}+\mathrm{CO}_{2}$ and $\mathrm{NCP}+\mathrm{ADP}+\mathrm{Pi} \rightarrow$ putrescine $+\mathrm{ATP}+\mathrm{NH}_{3}+\mathrm{CO}_{2}$ could be fol lowed upto DEAE-cellulose chromatography (table 2).

\section{The component enzyme activities}

Agmatine iminohydrolase activity and the arsenolytic cleavage reaction $(\mathrm{NCP} \rightarrow$ putrescine) share similar properties as those exhibited by the L. sativus enzyme (data not given). All the component activities as well as complete reactions had comparable $\mathrm{pH}$ optima to the enzyme activities catalyzed by L. sativus enzyme (data not given).

The carbamyl transferases: Ornithine transcarbamylase was the most stable activity among those harboured by the multifunctional enzyme. Both ornithine and putrescine transcarbamylase (N-carbamyl putrescine synthesis) depended on added DTT for their activity (table 4). $\mathrm{Mn}+$ or $\mathrm{Mg}^{2+}(1 \mathrm{mM})$ stimulated ornithine transcarbamylase but inhibited putrescine transcarbamylase activity.

Table 4. Comparison of carbamyltransferase activities of putrescine synthase from cucumber seedlings.

Activity units/mg protein

\begin{tabular}{lcc}
\cline { 2 - 3 } Assay conditions & $\begin{array}{c}\text { Ornithine transcarbamylase } \\
\text { (citrulline) }\end{array}$ & $\begin{array}{c}\text { Putrescine transcarbamylase } \\
\text { (N-Carbamyl putrescine) }\end{array}$ \\
\hline Control & 0.5 & 1.59 \\
$-\mathrm{DTT}$ & 0.36 & 0.88 \\
$+\mathrm{Mg}^{2+}(1 \mathrm{mM})$ & 1.46 & 0.47 \\
$+\mathrm{Mn}^{2+}(1 \mathrm{mM})$ & 1.41 & 0.94 \\
\hline
\end{tabular}

Citrulline and N-carbamyl putrescine were quantitated for measuring ornithine transcarbamylase and putrescine transcarbamylase (biosynthetic direction) activities ,respectively.

Overall reaction linked to ornithine transcarbamylase: The products of complete reaction linked to ornithine transcarbamylase, viz., putrescine and citrulline have been identified by paper chromatography. Unlike the component carbamyl transferase activities, the complete reaction exhibits an absolute requirement for dithiothreitol (DTT) (table 5). In the absence of $P i$ and $\mathrm{Mg}^{2+}$, very little of citrulline is produced as measured in ammonia eluates of Dowex-column.

\section{Discussion}

The data presented above clearly support the conclusion that the polycephalic putrescine synthase does function in cucumber system also, notwithstanding the greater complexity of its structural and functional organization vis-a-vis its 
Table 5. Requirements for the complete reaction coupled to ornithine transcarbamylase activity of putrescine synthase from cucumber seedings.

\begin{tabular}{lc}
\hline & $\begin{array}{c}\text { Activity units } \\
\text { Assay conditions }\end{array}$ \\
\hline Complete system & $19 \cdot()$ \\
- DTT & $2 \cdot(0)$ \\
- Ornithine & $3 \cdot 7$ \\
- Agmatine & Not detectable \\
$-P_{1}$ & $7 \cdot 4$ \\
$-\mathrm{Mg}^{2+}$ & $6 \cdot()$ \\
\hline
\end{tabular}

Agmatine + Ornithine $P_{i}$ Citrullinc + Putrescinc $+\mathrm{NH}_{3}$.

The complete assay mixture $(1.0 \mathrm{ml})$ consisted of $100 \mu \mathrm{mol}$ of Tris-HCI (pH 85), $2 \mathrm{mM}$ DTT. $5 \mathrm{mM} \mathrm{Mg}{ }^{2+} .5 \mathrm{mM} \mathrm{Na} \mathrm{HPO}_{4} .2 \cdot 5 \mu \mathrm{mol}$ agmatine and $5 \mu \mathrm{mol}$ of ornithine. Assay was initiated by the addition of $200 \mu \mathrm{g}$ of pure enzyme. Citrullinc was separated from agmatine by elution with $\mathrm{NH}_{4} \mathrm{OH}$ from a Dowex $50-\mathrm{H}$ column as described by Srivenugopal and Adiga (1981).

counterpart in L. sativus. The first indication that all the expected component activities are associated in a close structural and functional organization in this plant system also, stems from the coordinate changes in their individual catalytic activities during different stages of seedling growth (figure 1). Corroborative evidence for such intimate association is provided by the copurification of all the component activities as well as those mediating the overall reactions, during affinity chromatography on putrescine-CH-Sepharose column (tables 1 and 2). Among the major constraints towards further detailed characterization, the extreme lability and susceptibility of the enzyme to proteolysis dominated. Such impediments, however, were not totally unexpected since similar difficulties were encountered earlier with many other multifunctional proteins (Schweizer, 1980; Lampkin IV et al., 1976; Gaertner and Cole, 1977; Coleman et al., 1979). Additionally, the finding that the enzyme exists as two separable molecular entities EA and EM, with differing degree of catalytic efficiency added another dimension to the complexity (figure 2a, b; table 5). Although this initially raised the discrete possibility that the two molecular forms (EA and EM) are either isolation artifacts or represent isoenzymes contributed by different plant tissues (embryoaxes and cotyledons), further investigations revealed that they, indeed, represent different aggregated states of the same basic enzyme unit of $M_{r} 150,000$. While the exact relationship between the two molecular forms is still enigmatic, lower catalytic efficiency coupled with relative abundance of smaller sized constituent polypeptides of EM provide presumptive evidence for a precursor-product relationship between them. Another noteworthy feature of these constituent polypeptides is that they themselves seem to arise as the result of limited proteolytic modification of a larger biosynthetic unit (66 KDa species) of the enzyme. This is based on the observation that on translation of isolated mRNA from cucumber seedlings in a heterologous cell-free system (derived from rabbit reticulocyte lysates), immunoprecipitable radioactivity is associated with a single polypeptide chain of apparent $M_{r}$ of 66,000 (figure 5a). Similarly, such a biosynthetic precursor could be detected as the primary translational product in the homologous translation system prepared from 
6-day seedlings along with other smaller $M_{r}$ components characteristic of putrescine synthase enzyme as expected (figure 5b). The fact that the $66 \mathrm{KDa}$ protein is not detectable in putrescine synthase purified from day- 6 seedlings when peak activity was encountered (figures 1 and 4) raises the possibility that limited proteolysis may also be involved in the 'maturation' of enzyme to exhibit the maximum catalytic efficiency.

It is noteworthy that the age-dependent in vivo proteolytic modification of cucumber putrescine synthase has its counterparts in several of the multifunctional enzyme systems investigated hitherto. The classical examples of this category of enzyme are the 'arom' conjugate of $N$. crassa (Welch and Gaertner, 1980) and tryptophan synthase of yeast (Holzer et al., 1973; Crawford, 1980). Other examples for specific age-dependent proteolytic degradation of proteins are carbamyl phosphate synthase-aspartate transcarbamylase-dihydroorotate dehydratase of Drosophila (Azou et al., 1981) and cAMP dependent protein kinase of mouse (Beer et al., 1984). While the physiological significance of the age-dependent proteolysis of cucumber putrescine synthase is currently unclear, such specific degradation has been implicated in altered structural organization of chimeric enzymes leading to modified metabolic chanelling of reactants (Welch and Gaertner, 1980). As demonstrated with putrescine synthase in the present study, investigations on the 'arom' conjugate of $N$. crassa have shown that even when the enzyme protein suffers multiple proteolytic clips, the resultant polypeptides are still tenaciously held to retain the total catalytic efficiency and move as a single entity on alkaline-PAGE; only under severe denaturing conditions, they could be resolved into multiple bands. The analogy between the fungal enzyme and the plant putrescine synthase is obvious from the data presented.

In view of the complex pattern of constituent polypeptides of the cucumber putrescine synthase as observed on SDS-PAGE, an alternate possibility was considered that the enzyme might be harboring its associated activities more as a multi-enzyme complex rather than a single multifunctional entity. However, the nature of its primary translational product in the heterologous cell-free trans lational system together with age-dependent pattern of its constituent polypeptides do not seem to favour the above proposition.

Notwithstanding this greater complexity in terms of structural organization vis-a-vis L. sativus putrescine synthase (Srivenugopal and Adiga, 1981), the cucumber enzyme besides mediating all the constituent enzyme activities, also seems to catalyze the phosphorylytic conversion of $\mathrm{N}$-carbamyl putrescine to putrescine in a putrescine transcarbamylase-type of reaction. This is exemplified by the finding that (i) both $\mathrm{N}$-carbamyl putrescine synthesis and arsenolysis are mediated by the enzyme, (ii) the complete reaction viz.. agmatine $\rightarrow$ putrescine conversion, coupled to ornithine transcarbamylase requires both $\mathrm{Mg}^{2+}$ and $P_{i}$; citrulline production is untraceable in the absence of either of the substrates, viz.; agmatine or ornithine, (iii) both the transcarbamylases as well as the complete reactions require a reducing agent for optimal catalysis, (iv) requirements for arsenolysis are similar to those observed with L. sativus enzyme, (v) $\mathrm{pH}$ optima of various component enzymes fall within a narrow range and (vi) both the coupling activities, viz., ornithine transcarbamylase and carbamate kinase are demonstrable with agmatine as well as $\mathrm{N}$-carbamyl putrescine as substrates. It is significant that in the absence of $\mathrm{Pi}$, ornithine and ADP, the reaction does not progress beyond 
N-carbamyl putrescine, presumably due to the thermodynamic constraint for the phosphorylytic cleavage of $\mathrm{N}$-carbamyl putrescine by putrescine transcarbamylase (Roon and Barker, 1972). Of interest is the finding that the two coupled carbamyl transferases are differentially regulated by $\mathrm{Mg}^{2+}$ and $\mathrm{Mn}^{2+}$, in that ornithine transcarbamylase is stimulated by both the co-factors whereas putrescine transcar bamylase is inhibited (table 4). The stimulatory effect of ornithinetranscarbamy lase is in line with the finding that the complete reaction linked to ornithine transcarbamylase requires $\mathrm{Mg}^{2+}$ (table 5).

From the foregoing, the overall picture that emerges clearly support the concept that agmatine cycle proposed for L. sativus is also operative in cucumber system and that the multifunctional putrescine synthase catalyzing agmatine $\rightarrow$ putrescine transformation channellizes $\mathrm{N}$-carbamyl putrescine with resultant intact transfer of carbamyl group to support citrulline production thus conserving energy which otherwise would be dissipated.

\section{Acknowledgement}

The research work was supported by the grants from University Grants Commission, New Delhi.

\section{References}

Adiga, P. R. and Prasad, G. L. (1985) J. Plant Growth Regul., 3, 203-224.

Aviv, H. and Leder, P. (1972) Proc. Natl. Acad. Sci. USA, 69, 1408-1412.

Azou, Y., Mehl, Y. and Jarry, B. P. (1981) Dev. Biol., 84, 157-163.

Beer. D. G., Butley, M. S. and Malkinson, A. M. (1984) Arch. Biochem. Biophys., 228, $207-219$.

Campbell, D. H., Gravey, J. S., Grammer, N. E. and Susdorf, D. H. (1970) in Methods in Immunology. A Laboratory Text for Instruction and Research, (New York: W. A. Benjamin) pp. 189-253.

Crawford, I. P. (1980) Multifunctional Proteins (eds G. Bisswanger and E. Schminoke-Ott), (New York: John Wiley and Sons, A Wiley-Interscience Publications) pp. 151-174.

Crawford. L. V. and Gesteland, R. F. (1973) J. Mol . Biol. , 74, 627-634.

Cohen, W. E. and Carter, C. E. (1950) J. Am. Chem. Soc., 72, 4273-4275.

Coleman, P. F., Suttie, D. P. and Stark, G. R. (1979) J. Biol. Chem., 252, 6379-6385.

Davis, B. J. (1964) Ann. N. Y. Acad. Sci., 121, 404-427.

Gaertner, F. H. and Cole, K. W. (1976) Arch. Biochem. Biophys., 177, 566-573.

Gaertner, F. H. and Cole, K. W. (1977) Biochem. Biophys. Res. Commun., 75, 259-264.

Holzer, H., Katsumuma, T., Schott E. G , Hasilik, A. and Betz, H. (1973) Adv. Enzyme Regul., 11, 53-60.

Laemmli, U. K. (1970) Nature (London), 227, 680-685.

Lampkin, IV, S. L., Cole, K. W., Vitto, A. and Gaertner, F. H. (1976) Arch. Biochem. Biophys., 177, $561-565$.

Lamprecht, W. and Trautschold, I. (1974) in Methods of Enzymatic Analysis (ed. U. H. Bergmeyer) vol. 4, pp. 2101-2110.

Lowry, O. H., Rosebrough, N. J., Farr, A. L. and Randall, R. Y. (1951)J. Biol. Chem., 193, 265-275.

Morris, D. R. and Pardee, A. B. (1966) J. Biol . Chem., 241, 3129-3135.

Ouchterlony, O. (1967) in Handbook of Experimental Immunology (ed. D. M. Weir) (Oxford, Edinburgh: Blackwell Scientific Publications) pp. 655-706.

Palmiter, R. D. (1974) Biochemistry, 13, 3606-3615.

Percival, F. W. and Purves, W. K. (1974) Plant Physiol., 54, 601-607.

Ravishankar, H. and Padmanaban, G. (1983) Arch. Biochem. Biophys., 225, 16-24.

Roon, R. J. and Barker, H. A. (1972) J. Bacteriol., 109, 44-50. 
Schweizer, E. (1980) Multifunctional Proteins (eds H. Bisswanger and E. Schmincke-Ott) (New York: John Wiley and Sons, A Wiley- Interscience Publication) pp. 197-215.

Srivenugopal. K. S. and Adiga. P. R. (1980) Anal. Biochem., 104, 440-444.

Srivenugopal, K. S. and Adiga, P. R. (1981) J. Biol. Chem., 256, 9532-9541.

Srivenugopal, K. S. and Adiga, P. R. (1983a) Methods Enzymol., 94, 335-339.

Srivenugopal, K. S. and Adiga, P. R. (1983b) Methods Enzymol., 94, 429-430.

Srivatsan, E. S. and Padayatty, J. D. (1976) Indian J. Biochem. Biophys., 13, 284-286.

Smith, T. A. (1963) Phytochemistry, 2, 241-252.

Smith, T. A. (1965) Phytochemistry, 4, 599-607.

Smith,T. A. (1970) Ann. N.Y. Acad. Sci., 171, 988-1001.

Smith,T. A. (1971) Biol. Rev., 46,201-241.

Smith,T. A. and Garraway. J. L. (1964) Phytochemistry, 3, 23-26.

Tabor, H. and Tabor, C. W. (1972) Adv. Enzymol., 36, 203-268.

Tabor, C. W. and Tabor, H. (1984) Ann. Rev. Biochem., 53, 749-790.

Welch, R. G. and Gaertner, F. H. (1980) Curr. Top. Cell . Regul., 16, 113-162. 